\title{
Pine needle effects on in vivo and in vitro diges- tibility of crested wheatgrass
}

\author{
DON C. ADAMS, JAMES A. PFISTER, ROBERT E. SHORT, REX G. CATES, BRAD \\ W. KNAPP, AND RANDALL D. WIEDMEIER
}

\begin{abstract}
Adams is associate professor, Univ. of Nebraska, Institute of Agriculture and Natural Resources, West Central Res. and Ext. Center, Route 4, Box 46A, North Platte 69101; Pfister is range scientist, USDA-ARS Poisonous Plant Research Lab., Logan, Utah 84321; Short and Knapp are research physiologist and statistician, USDA-ARS Ft. Keogh Livestock and Range Research Lab., Miles City, Montana; Cates is professor, of botany and range science, Brigham Young Univ., Provo, Utah; Wiedmeier is assistant professor, animal, dairy and veterinary science, Utah State Univ., Logan.
\end{abstract}

\begin{abstract}
In vitro and in vivo digestion trials with lambs were conducted to determine effects of ponderosa pine needles (PN; Pinus ponderosa Laws.) on digestibility of crested wheatgrass (CW; Agropyron desertorum [Link] Schultes) hay. Pine needles contained shikimic acid (15-28 $\mathrm{mg} / \mathrm{g}$ ) and several monomeric phenolics (p-hydroxy benzoid acid, caffeic acid, p-coumaric acid, ferulic acid) and flavonoids. Tannin concentration exceeded assay limits $>10 \%$ ) and terpenes were not found, probably due to the drying procedure. In the in vitro trial, needles were mixed with $\mathrm{CW}$ in $10 \%$ increments from $0 \%$ to $100 \%$. In the in vivo trial, PN were fed to lambs as follows: (1) $0 \%,(2) 12.5 \%$, (3) $25 \%$, and (4) $50 \%$, with the remainder of the diet as CW. In vitro organic matter digestibility (IVOMD) was regressed on level of $P N$ in the substrate. As the proportion of PN increased, IVOMD declined cubicly $(P<0.01)$. The IVOMD values ranged from $54 \%$ for $100 \% \mathrm{CW}$ to $24 \%$ for $100 \% \mathrm{PN}$. In vivo digestibility of organic matter, neutral detergent fiber and acid detergent fiber declined linearly $(P<0.01)$ as $P N$ were increased from $\mathbf{0 \%}$ to $50 \%$ of the diet. Apparent crude protein digestibility and $N$ retention by lambs declined cubicly $(P=0.02$ and $P<0.01$, respectively) and urinary $N$ increased cubicly $(P<0.01)$ as dietary PN increased from $0 \%$ to $50 \%$. We concluded that PN reduce in vitro and in vivo nutrient digestibility, reduced $N$ retention by lambs, and effects were detectable even at low levels.
\end{abstract}

\footnotetext{
Publication has been approved by the director of the Montana Agr. Exp. Sta., Journal Ser. J-2476.

Manuscript accepted 4 September 1991
}

Key Words: Pinus ponderosa, plant secondary compounds, sheep toxic effects, poisonous plants, nitrogen retention

Cattle grazing winter range consume variable but sometimes large quantities of ponderosa pine needles (PN; Pinus ponderosa Laws.; Pfister and Adams 1991). Consumption of needles from ponderosa pine causes abortion (James et al. 1977), retained placentas, and endometritis in cattle (Stuart et al. 1989). Pine trees grow in much of the western U.S., and pine needle abortion has a severe impact on livestock producers in areas with ponderosa pine (Lacey et al. 1988).

Pine needles contain a number of secondary phytochemicals such as phenolics, terpenes, and tannins (Smith 1964, Hanover 1966). Levels of secondary compounds and forage digestibility are negatively correlated (Jung and Fahey 1981, Akin 1982, Jung 1985); phenolics also negatively impact rumen microbial populations (Akin 1982, Chesson et al. 1982).

Despite the negative effects of pine needles on cattle reproduction and possible negative influences of pine needles on forage digestibility, there is little information available on effects of pine needles on digestion and metabolism of ruminants. The objectives of this study were to determine effects of pine needles on digestibility in vitro and in vivo and on $\mathrm{N}$ retention in lambs. Our hypothesis was that pine needles would reduce forage digestibility and $\mathrm{N}$ retention. 


\section{Materials and Methods}

\section{Digestibility Trials}

In vitro and in vivo digestion trials were conducted to determine effects of PN on digestibility of crested wheatgrass (CW; Agropyron desertorum [Link] Schultes) hay. Mature (full seedhead) CW hay was harvested from a 13-ha site $1 \mathrm{~km}$ west of Miles City, Mont. Crested wheatgrass was selected because it is often grazed and/or fed as a hay on sites with ponderosa pine where cattle are wintered. Green PN on branches from trees were collected in the spring and fall at a site about $20 \mathrm{~km}$ east of Miles City, Mont., and were air dried in a room at $20^{\circ} \mathrm{C}$. After drying, PN were stripped by hand from branches. Spring PN were fed with $\mathrm{CW}$ to lambs (average weight $=26 \mathrm{~kg}$ ) in a conventional digestion trial. Treatments were diets of (1) $100 \% \mathrm{CW},(2) 87.5 \% \mathrm{CW}$ and $12.5 \% \mathrm{PN}$, (3) $75 \% \mathrm{CW}$ and $25 \% \mathrm{PN}$, and (4) $50 \% \mathrm{CW}$ and $50 \% \mathrm{PN}$. Before feeding, $\mathrm{CW}$ and $\mathrm{PN}$ were ground through a hammermill with a $2.5-\mathrm{cm}$ screen. Sixteen crossbred (primarily Targhee $X$ Suffolk $X$ Hampshire) wether lambs were utilized in the digestion trial. The trial consisted of 2 periods with 8 lambs per period ( 2 lambs/ treatment). Lambs were fed experimental diets for a 12-day adjustment period, followed by a 7-day total collection of feces and urine. Lambs were fed at $\mathbf{0 7 0 0}$ and 1600 daily $(90 \%$ of their ad libitum intake during 12-day adjustment period) during the collection period. Feces and urine were collected daily, and composited by lamb across days and frozen until laboratory analysis. The $\mathrm{CW}$ and PN were sampled daily and composited across days and lambs within each period for chemical analysis. In a few instances, there were some orts from $\mathrm{PN}$ or $\mathrm{CW}$ during the collection period. Orts were collected and composited across days for each lamb.

Dry matter (DM), ash, and $\mathrm{N}$ in feed, orts and fecal samples and $\mathrm{N}$ content of urine were determined by standard methods (AOAC 1984). Neutral detergent fiber (NDF) and acid detergent fiber (ADF) content were determined in feed and fecal samples by the procedure of Goering and Van Soest (1970).

Intake of DM, ash, N, NDF, and ADF was adjusted for content in orts. Digestion coefficients for DM, organic matter, NDF, $\mathrm{ADF}$, and the apparent digestion coefficient for crude protein were calculated as described by Schneider and Flatt (1975).

Spring-and fall-collected $P N$ were mixed in varying proportions with $\mathrm{CW}$ in an in vitro digestion study. The $\mathrm{CW}$ for both in vitro trials was a subsample of $\mathrm{CW}$ used in the in vivo trial. Before in vitro digestion, $P N$ and $C W$ were ground to pass a $1-\mathrm{mm}$ screen in a Wiley mill. In independent trials (i.e., different dates) using spring or fall PN, substrate was varied from $100 \% \mathrm{CW}$ to $100 \% \mathrm{PN}$ in $10 \%$ increments. To more precisely define PN effects at low levels, the fall PN, substrate was also varied from $100 \mathrm{CW} \%$ to $80 \% \mathrm{CW}$ by adding $\mathrm{PN}$ in $2 \%$ increments.

In vitro organic matter digestibility (IVOMD) was determined in triplicate for spring and quadruplicate for fall $P N$ for each PN:CW combination with a modified (Cochran et al. 1986) 2-stage Tilley and Terry (1963) procedure. Rumen fluid inoculum for the in vitro trials was collected through a rumen fistula from a steer maintained on a diet of $\mathrm{CW}$ hay. Rumen fluid was collected approximately 4 hours after feeding for both in vitro trials. Rumen fluid was strained through 8 layers of cheese cloth and samples within each trial were handled simultaneously within a single run. Spring and fall in vitro trials were conducted independently on 2 separate dates.

The in vivo trial was analyzed as a randomized complete block by analysis of variance. Dry matter intake was tested as a covariate for each digestion coefficient, urinary $\mathbf{N}$ excretion, and $\mathbf{N}$ balance. When the covariate was significant, means were adjusted to a common dry matter intake. Treatment means for each digestion coefficient, urinary $\mathrm{N}$ excretion and $\mathrm{N}$ balance were compared with orthogonal polynomials (Steel and Torrie 1980). In vitro trials were analyzed by regression techniques. In vitro organic matter digestibility was regressed on level of PN in substrate. Linear, quadratic, and cubic regression coefficients were tested, as was the season $X$ level of PN interaction. Linear, quadratic and cubic regression coefficients were tested for incubations of fall PN in $2 \%$ increments.

\section{Chemical Methods for Pine Needle Analysis \\ Carbohydrates, Acids, and an Alcohol}

Pine needle tissue was air dried and ground through a $1-\mathrm{mm}$ screen through a Wiley mill. Ground tissue $(500 \mathrm{mg})$ was extracted in $80 / 20$ methanol/water $(20 \mathrm{ml})$. A 9-ml aliquot was blown dry, taken up in pyridine, and $0.5 \mathrm{mg}$ erythritol, the internal standard, was added. The compounds in solution were derivitized with trimethylchlorosilane and hexamethyldisilazane. A $5 \mu 1$ aliquot of the supernatant was injected into a Hewlett Packard capillary gas chromatograph equipped with a $100 \%$ methyl polysilozane, $25-\mathrm{m}$ column. Nitrogen was the carrier gas at $0.5 \mathrm{ml} / \mathrm{min}$. Injector temperature was $250^{\circ} \mathrm{C}$, detector temperature was $260^{\circ} \mathrm{C}$, and initial temperature was $100^{\circ} \mathrm{C}$ for $1 \mathrm{~min}$. Compounds were identified by co-chromatography using known standards. Data for these compounds, as well as all other compounds, were expressed as $\mathrm{mg} / \mathrm{g}$ dry weight of tissue.

\section{Monomeric phenolics}

Air dried, ground plant tissue ( $500 \mathrm{mg}$ ) was extracted in $8 \mathrm{ml}$ $100 \%$ methanol. This was concentrated to $4 \mathrm{ml}$ under $\mathrm{N}$ at $46^{\circ} \mathrm{C}$. Water was added, the extract was washed with $8 \mathrm{ml}$ hexane, and blown dry at $46^{\circ} \mathrm{C}$. Methanol/HCL $(0.5 \mathrm{ul})$ was added to the extract, the extract was heated to $100^{\circ} \mathrm{C}$ for $30 \mathrm{~min}$, and then $1 \mathrm{ml}$ water was added. This was extracted with $1.5 \mathrm{ml}$ ethyl acetate, dried using $\mathrm{Na}_{2} \mathrm{SO}_{4}$, and the internal standard vanillic acid was added $(0.25 \mathrm{mg})$. This was blown dry as above, derivitized in $100 \mu 1$ dimethylformamide and d100 $\mu \mathrm{l}$ bis-trifluoracetamide plus $1 \%$ trimethylchlorosilane, and $5 \mu \mathrm{l}$ were injected in a Hewlett Packard capillary gas chromatograph (GC). The GC was equipped with a Hewlett Packard ultra 2, 5\% phenyl/5\% methylsilicone column, $25-\mathrm{m}$ long, and ID $0.32 \mathrm{~mm}$. The temperature regime is that described for carbohydrates. Compounds were identified by cochromatography using known standards.

\section{Tannins as Analyzed by Astringency}

Because the ecologically important property of tannins has been suggested to be astringency (i.e., protein-complexing activity), tannin content was analyzed by the astringency method (Horner et al. 1987). Air dried, ground plant ( $200 \mathrm{mg}$ ) was extracted in $70 \%$ acetone. Acetone was removed by passing $\mathrm{N}$ over the supernatant at $55^{\circ} \mathrm{C}$, filtered through a $0.45 \mu \mathrm{m}$ nylon filter and hemolglobin solution used as the reaction protein. The astringency of the tissue is expressed as that relative to the standard quebracho tannin.

\section{Results}

\section{Pine Needle Chemistry}

Pine needles contained several carbohydrates; galactose was the most prevalent (Table 1). Two acids, shikimic and citric acid, were present in PN tissue (Table 1). An alcohol, inositol, was also found in needles. The spring and fall pine needles had large numerical differences in levels of several carbohydrates and shikimic acid.

We found several monomeric phenolic acids in PN tissue; flavonoids were also present in needles (Table 1). Terpenes were not detected in PN tissue, probably due to volatilization during airdrying plant material. Tannins were present in large quantities (i.e., $>10 \%$ ), exceeding detection limits of the astringency technique used. Fall and spring needles differed quantitatively in levels of several phenolic and flavonoid compounds; the biological signifi- 
Table 1. Carbohydrates, acids, an alcohol, phenolic monomers, tannins, flavonids, and terpenes ( $\mathrm{mg} / \mathrm{g}$ dry weight) in pine needle (PN) tissue collected during fall and spring in eastern Montana.

\begin{tabular}{|c|c|c|}
\hline Class of compound/chemical & Spring PNI & Fall PN \\
\hline & Carbohydrate & $\mathrm{mg} / \mathrm{g}$ \\
\hline Fructose & 8.78 & 4.29 \\
\hline Galactose & 16.30 & 23.86 \\
\hline Glucose & 10.20 & 4.83 \\
\hline Mannose & 0.84 & 0.42 \\
\hline Sucrose & 3.58 & 9.25 \\
\hline \multicolumn{3}{|l|}{ Acids } \\
\hline Shikimic acid & 15.94 & 27.76 \\
\hline Citric acid & 2.43 & 2.58 \\
\hline \multicolumn{3}{|l|}{ Alcohol } \\
\hline Inositol & 1.10 & 0.61 \\
\hline \multicolumn{3}{|l|}{ Monomeric phenolic acids } \\
\hline p-hydroxy benzoic acid & 0.085 & 0.118 \\
\hline caffeic acid & 0.008 & 0.016 \\
\hline p-coumaric acid & 0.082 & 0.000 \\
\hline ferulic acid & 0.049 & 0.052 \\
\hline gallic acid & 0.154 & 0.493 \\
\hline vanillic acid & 0.059 & 0.058 \\
\hline \multicolumn{3}{|l|}{ Flavonoids } \\
\hline kaempferol & 0.025 & 0.039 \\
\hline naringen & 1.429 & 1.750 \\
\hline quercetin & 0.000 & 0.214 \\
\hline taxifolin & 0.128 & 0.075 \\
\hline \multicolumn{3}{|l|}{ Terpenes } \\
\hline $\begin{array}{l}\text { alpha-pinene } \\
\text { beta-pinene }\end{array}$ & $\begin{array}{l}\text { absent } \\
\text { absent }\end{array}$ & $\begin{array}{l}\text { absent } \\
\text { absent }\end{array}$ \\
\hline Tannins $^{2}$ & present & present \\
\hline
\end{tabular}

1 Pine needles used in an in vitro and in vivo trial.

'Tannin concentration was not quantified because levels exceeded detection limits $(>10 \%)$ of the method used.

cance of these differences is unknown in the context of our study.

Nutrient composition of $\mathrm{CW}$ and PN used during the study is shown in Table 2 . Although collected at 2 seasons, nutrient composition of needles was similar.

\section{In vivo Trial}

Digestion coefficients for the in vivo trial are presented in Table 3. Dry matter intake as a covariate was not significant $(P>0.05)$ for digestibility of any nutrient measured. In vivo digestibility of $\mathrm{DM}$, OM, NDF, and ADF declined linearly $(P<0.01)$ with increasing levels of PN in the diet. However, there was a consistent trend ( $P=$ 0.09 to $P=0.20$ ) for a cubic relationship between level of $P N$ and digestibility for each of these 4 variables. The cubic relationships
Table 2. Nutrient composition of crested wheatgrass (CW) and pine needles (PN) used in digestion trials'.

\begin{tabular}{lccc}
\hline \hline Item & CW & Spring PN2 & Fall PN \\
\hline Dry matter (\%) & 91.7 & 92.7 & 92.2 \\
Organic matter (\%) & 95.0 & 96.5 & 97.6 \\
Crude protein (\%) & 5.9 & 7.8 & 6.5 \\
Neutral detergent fiber (\%) & 70.5 & 54.8 & 49.9 \\
Acid detergent fiber (\%) & 40.6 & 42.3 & 36.9 \\
\hline
\end{tabular}

'Dry matter basis.

${ }_{2}^{2}$ Pine needles used in an in vitro and in vivo trial.

each revealed a large reduction in digestibility between the $0 \%$ and $12.5 \%$ levels of PN. The digestion coefficients for $12.5 \%$ and $25 \%$ PN levels were similar, and a large reduction in digestibility occurred as PN proportion was increased from 25 to 50\%. Apparent digestibility of crude protein was markedly different at all levels of PN (Table 3). A cubic relationship ( $P=0.02$ ) occurred between dietary PN proportion and crude protein digestibility. Apparent protein digestibility was reduced by more than $90 \%$ as PN were increased from $0 \%$ to $50 \%$ of the diet.

Dry matter intake significantly affected urinary $N$ excretion and $\mathrm{N}$ retention by lambs; therefore, urinary $\mathrm{N}$ and $\mathrm{N}$ retention were adjusted to a common level of intake. Dry matter intake was 17.0, $16.6,16.0$, and $12.0 \mathrm{~g} / \mathrm{kg}$ of body weight for diets containing $0 \%$, $12.5 \%, 25 \%$, and $50 \% \mathrm{PN}$, respectively. The relationship between $\mathrm{N}$ excreted in the urine and dietary PN percentage was cubic $(P=$ 0.02). Excretion of $\mathrm{N}$ in the urine declined slightly as $P N$ percentage was increased from $0 \%$ to $25 \%$. A large increase in urinary $\mathrm{N}$ excretion occurred between the $25 \%$ and $50 \%$ levels of PN.

Nitrogen retention was negative for lambs on all treatments (Table 3). The relationship between $\mathrm{N}$ retained and level of PN consumption was cubic $(P<0.01)$. Nitrogen retention declined slightly between the $0 \%$ and $12.5 \%$ levels of $\mathrm{PN}$, then increased slightly as PN were increased from $12.5 \%$ to $25 \%$ of the diet. A large reduction in $\mathrm{N}$ retention occurred between the $25 \%$ and $50 \%$ PN levels.

\section{In vitro Trial}

A cubic relationship occurred between IVOMD and level of PN for fall and spring PN in $10 \%$ increments from $0 \%$ to $100 \%$ of substrate. The season $\times$ level of $P N$ interaction was not significant, nor were regression coefficients different for fall and spring PN. Thus, a single cubic $\left(P<0.01 ; R^{2}=0.99\right)$ regression equation represented the relationship between level of PN and IVOMD for both spring and fall PN (Fig. 1). The IVOMD declined rapidly as PN increased from $0 \%$ to $50 \%$ and then declined at a much slower rate from $50 \%$ to $100 \% \mathrm{PN}$.

The IVOMD declined linearly $\left(P<0.01 ; R^{2}=0.74\right)$ as $\mathrm{PN}$ replaced CW substrate in $2 \%$ increments from $0 \%$ to $20 \%$. The

Table 3. Effects of pine needles on digestibility of dry matter (DM), organic matter (OM), neutral detergent fiber (NDF), acid detergent fiher (ADF) and crude protein (CP), and on urinary $N$ excretion (UN) and $N$ retained (NR) by lambs.

\begin{tabular}{|c|c|c|c|c|c|c|c|c|}
\hline \multirow[b]{2}{*}{ Variable } & \multicolumn{4}{|c|}{ Percent of pine needles in the diet ${ }^{2}$} & \multicolumn{3}{|c|}{ Significance of orthogonal polynomial ${ }^{3}$} & \multirow[b]{2}{*}{ EMS $^{4}$} \\
\hline & 0 & 12.5 & 25 & 50 & $\mathbf{L}$ & $\mathbf{Q}$ & C & \\
\hline DM (\%) & 58.7 & 50.6 & 51.0 & 41.8 & $P<0.01$ & $P>0.2$ & $\mathrm{P}=0.09$ & 16.6 \\
\hline OM $(\%)$ & 60.6 & 52.7 & 52.5 & 43.7 & $P<0.01$ & $P>0.2$ & $\mathrm{P}=0.14$ & 17.6 \\
\hline NDF $(\%)$ & 58.8 & 49.4 & 44.4 & 31.0 & $P<0.01$ & $P>0.2$ & $P=0.20$ & 15.7 \\
\hline ADF $(\%)$ & 52.4 & 39.8 & 37.3 & 24.5 & $P<0.01$ & $P>0.2$ & $\mathrm{P}=0.20$ & 40.5 \\
\hline CP $(\%)$ & 43.9 & 22.9 & 30.6 & 3.9 & $P<0.01$ & $P<0.01$ & $P=0.02$ & 83.6 \\
\hline UN (g/day) & 2.8 & 2.5 & 2.3 & 8.4 & $P<0.01$ & $P<0.01$ & $\mathrm{P}=0.02$ & 0.42 \\
\hline NR (g/day) & -0.1 & -1.3 & -1.0 & -7.7 & $P<0.01$ & $P<0.01$ & $P<0.01$ & 0.30 \\
\hline
\end{tabular}

IDigestibility coefficients are on a dry matter basis.

2Remainder of diet was crested wheatgrass hay.

${ }^{3} \mathrm{~L}=$ linear, $\mathrm{Q}=$ quadratic, $\mathrm{C}=$ cubic, $\mathrm{N}=4$.

EMS = Error mean squares. 


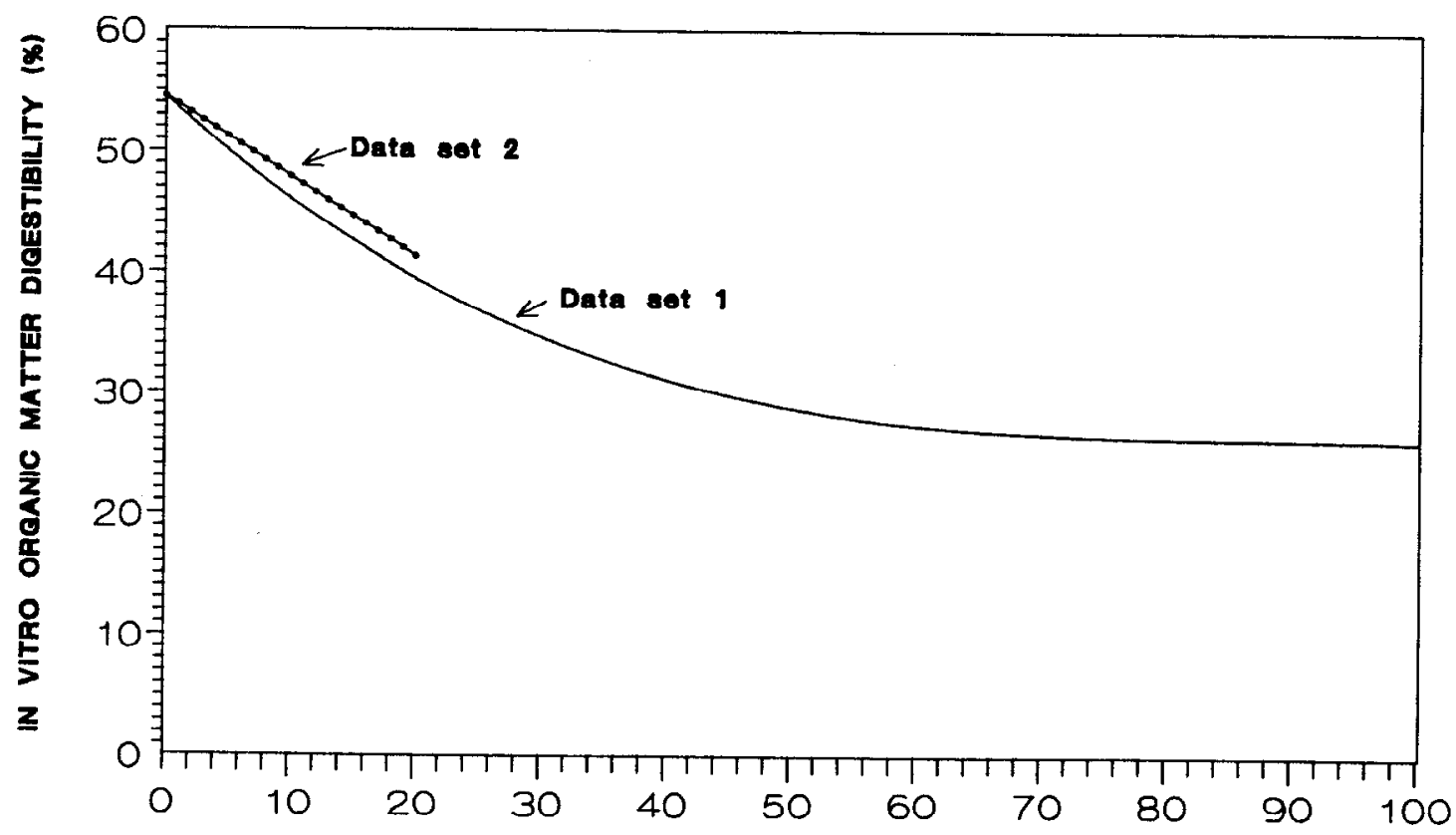

PERCENT OF PINE NEEDLES IN THE IN VITRO SUBStRATE

Fig. 1. Effects of increasing level of pine needles on in vitro organic matter digestibility of a crested wheatgrass hay-based substrate. In Data set 1 , pine needles varied from $0 \%$ to $100 \%$ of the in vitro substrate in $10 \%$ increments (regression: $Y=54.5-.944 X+1.06 \times 10^{-2} X^{2}-4.00 \times 10^{-5} X^{3}, R^{3}=.99$ ). In Data set 2, pine needles varied from $0 \%$ to $20 \%$ of the in vitro substrate in $2 \%$ increments (regression: $Y=54.5-.660 X, R^{2}=.74$ ).

inhibitory effect of PN on digestibility added in smaller increments produced a similar relationship as when $P N$ were added in larger amounts (Fig. 1).

\section{Discussion}

Pine needles contained a number of secondary phytochemicals that have been shown to depress forage digestibility. For example, Jung (1985) and Cherney et al. (1989) found that benzoic, cinnamic (e.g., p-coumaric and ferulic acid), and caffeic acids depressed digestion of cellulose. Flavonol glycosides (e.g., kaempferol) are also of interest (Strack et al. 1988) because these compounds may limit degradation of plant material in ruminants (Huang et al. 1986). The predominant acid in PN tissue, shikimic acid, is a major precursor of cinnamic acid and lignin in plant tissue (Goodwin and Mercer 1972).

There are numerous published reports that indicate tannins have negative impacts on digestibility (Kumar and Singh 1984). The high level of tannins found in our study may have inhibited microbial breakdown of plant cell wall (Cooper and Owen-Smith 1985). However, it appears unlikely that dietary tannins inhibit digestion through inhibition of digestive enzymes (Bernays et al. 1989). Under in vivo conditions, dietary tannins are generally not accessible to digestive enzymes (Butler et al. 1984, Mehansho et al. 1983). Tannins have been shown to be much more deleterious under in vitro conditions (Blytt et al. 1988).

Isolation of crude extracts and individual compounds and testing their effects in an in vitro system will be required in future work to determine which compound(s) is most inhibiting to forage digestion.

The reduction of digestibility observed for dietary components examined in this study is consistent with findings for other plant species containing various phytochemicals (Barry and Manley 1986, Jung 1985, Palo 1985, Burritt et al. 1984). Organic matter digestibility declined as $\mathrm{PN}$ percentage increased with both in vitro and in vivo digestion. Surprisingly, the impacts of PN on digestibil- ity traits were observed at as little as $2 \% \mathrm{PN}$ in vitro and had a marked effect at $12.5 \%$ of the diet with lambs.

The effects of PN were greater for in vitro than for in vivo digestion, and the difference became greater as level of PN increased. Our findings suggest that toxic effects of PN metabolism accumulate at higher levels in in vitro compared to in vivo systems, accentuating $P N$ effects in vitro.

Although PN reduced digestibility of all nutrients in the in vivo trial, the most striking effect was on digestibility of crude protein. The negative effects of PN on digestibility are at least partially due to effects of phenolics or other secondary compounds on rumen microbial populations (Wiedmeier, unpublished data); other studies have noted that low molecular weight phenolics limit microbial degradation of structural carbohydrates (Akin 1982, Chesson et al. 1982).

We found a large inhibition of protein digestibility with PN inclusion in diets. Research at our laboratory (Pfister, unpublished data) with cattle consuming pine needles has shown that PN levels about $15 \%$ of the diet reduce ammonia- $\mathrm{N}$ concentrations below levels adequate for ruminal function, which would further reduce forage digestibility (Slyter et al. 1979, Qrskov 1982).

Nitrogen retention was negative for all levels of PN because of low levels of intake and concentrations of crude protein in the diet. The high negative $\mathrm{N}$ balance at the $50 \%$ level of dietary PN is explained by the $3.9 \%$ apparent crude protein digestibility and the $8.4 \mathrm{~g} \mathrm{~N} /$ day excreted in the urine. At some point between the $25 \%$ and $50 \%$ level of PN, increasing the level of dietary PN increases $N$ passing through the feces and urine and profoundly reduces $\mathbf{N}$ retention. Ingestion of browse material commonly results in poor $\mathrm{N}$ retention in ruminant livestock. Holechek et al. (1990) fed 6 shrub diets varying in phenol content to goats, and found that all diets produced a negative $\mathrm{N}$ balance.

From relationships between PN consumption and digestibility coefficients and $\mathrm{N}$ retention observed in this study, we conclude that $\mathrm{PN}$ at low levels adversely affect in vitro and in vivo forage digestibility and $\mathrm{N}$ retention. Because of the adverse effects of PN 
on digestibility and $\mathrm{N}$ retention, $\mathrm{PN}$ may have negative impacts on the nutritional status of cattle (i.e., loss of live weight), in addition to abortifacient effects.

\section{Literature Cited}

Akin, D.E. 1982. Forage cell wall degradation and p-coumaric, ferulic and sinapic acids. Agron. J. 74:424-428.

AOAC. 1984. Official methods of analysis (14th ed.). Association of Official Analytical Chemists. Washington, D.C.

Barry, T.N., and T.R. Manley. 1986. Interrelationships between the concentrations of total condensed tannins, free condensed tannins and lignin in Lotus spp. and their possible consequences in ruminant nutrition. $J$. Sci. Food Agr. 37:248-254.

Bernays, E.A., G. Cooper Driver, and M. Bílgener. 1989. Herbivores and plant tannins. Adv. Ecol. Res. 19:263-302.

Blytt, H.J., T.K. Guscar, and L.G. Butler. 1988. Antinut ritional effects and ecological significance of dietary condensed tannins may not be due to binding and inhibiting digestive enzymes. J. Chem. Ecol. 14:1455-1465.

Burritt, E.A., A.S. Bittner, J.C. Street, and M.J. Anderson. 1984. Correlations of phenolic acids and xylose content of cell wall with in vitro dry matter digestibility of three maturing grasses. J. Dairy Sci. 67:1209-1213.

Butler, L.G., D.J. Reidl, D.G. Lebryk, and H.J. Blytt. 1984. Interaction of proteins with sorghum tannin: mechanism, specificity and significance. J. Amer. Oil Chem. Soc. 61:916-920.

Cherney, J.H., K.S. Anliker, K.A. Albrecht, and K.V. Wood. 1989. Soluble phenolic monomers in forage crops. J. Agr. Food Chem. 37:345-350.

Chesson, A., C.S. Steward, and R.J. Wallace. 1982. Influence of plant phenolic acids on growth and cellulolytic activity of rumen bacteria. Appl. Environ. Microbiol. 44:597-603.

Cochran, R.C., D.C. Adams, J.D. Wallace, and M.L. Galyean. 1986. Predicting digestibility of different diets with internal markers: evaluation of four potential markers. J. Anim. Sci. 63:1476-1483.

Cooper, S.M., and N. Owen-Smith. 1985. Condensed tannins deter feeding by browsing ungulates in a South African savanna. Oecologia 67:142-146.

Goering, H.K., and P.J. Van Soest. 1970. Forage fiber analysis (apparatus, reagents, procedures, and some applications). ARS, USDA Agr. Handb. 379.

Goodwin, T.W., and E.I. Mercer. 1972. Introduction to plant biochemistry. Pergamon Press, N.Y

Hanover, J.W. 1966. Environmental variation in the monoterpenes of Pinus monticola Dougl. Phytochemistry 5:713-717.

Holechek, J.L., A.V. Munshikpu, L. Saiwana, G. Nunez-Hernandez, R. Valdez, J.D. Wallace, and M. Cardenas. 1990. Influences of six shrub diets varying in phenol content on intake and nitrogen retention by goats. Trop. Grassl. 24:93-98.
Horner, J., R.G. Cates, and J. Gosz. 1987. Tannin, nitrogen, and cell wall composition of green vs, senescent Douglas-fir foliage: within and between stand differences in stands of unequal density. Oecologia 72:515-519.

Huang, H.M., G.L. Johanning, and B.L. O'Dell. 1986. Phenolic acid content of food plants and possible nutritional implications. J. Agr. Food Chem. 34:48-51.

James, L.F., J.W. Call, and A.H. Stevenson. 1977. Experimentally induced pine needle abortion in range cattle. Cornell Vet. 67:294-299.

Jung, H.G. 1985. Inhibition of structural carbohydrate fermentation by forage phenolics. J. Sci. Food Agr. 36:74-80.

Jung, H.G., and G.C. Fahey, Jr, 1981. Effect of phenolic compound removal on in vitro forage digestibility. J. Agr. Food Chem. 29:817-820.

Kumar, R., and M. Singh. 1984. Tannins: their adverse role in ruminant nutrition. J. Agr. Food Chem. 32:447-453.

Lacey, J.L., L.F. James, and R.E. Short. 1988. Ponderosa pine: economic impact, p. 95-106. In: L.F. James, D.B. Nielsen and M.H. Ralphs (eds.), The Ecology and Economic Impact of Poisonous Plants on Livestock Production, Westview Press, Boulder, Colo.

Mehansho, H., A. Hagerman, S. Clements, L. Rogler, and D.M. Carison. 1983. Studies on environmental effects of gene expression: modulation of proline-rich protein biosynthesis in rat parotid glands by sorghums with high tannin levels. Proc. Nat. Acad. USA 80:3948-3952.

Grskov, E.R. 1982. Protein nutrition in ruminants. Academic Press, N.Y.

Palo, R.T. 1985. Chemical defense in hirch: inhibition of digestibility in ruminants by phenolic extracts. Oecologia 68:10-14

Pfister, J.A., and D.C. Adams. 1991. Consumption of toxic pine needles by grazing cattle during winter. $J$. Range Manage. in review.

Schneider, B.H., and W.P. Flatt. 1975. The evaluation of feeds through digestibility experiments. The University of Georgia Press, Athens.

Slyter, L.L., L.D. Satter, and D.A. Dinius. 1979. Effect of ruminal ammonia concentration on nitrogen utilization by steers. J. Anim. Sci. 48:906-912.

Smith, R.N. 1964. Variation in the monoterpenes of Pinus ponderosa Laws. Science 143:1337-1338.

Steel, R.G.D., and J.H. Torrie. 1980. Principles and procedures of statistics (2nd ed.). McGraw-Hill Book Co., N.Y

Strack, D., J. Heilemann, M. Momken, and V. Wray. 1988. Cell wall conjugated phenolics from coniferae leaves. Phytochemistry 27:35173521.

Stuart, L.D., L.F. James, K.E. Panter, J.W. Call, and R.E. Short. 1989. Pine needle abortion in cattle: pathological considerations. Cornell Vet. 79:61-69.

Tilley, J.M.A., and R.A. Terry. 1963. A two-stage technique for the in vitro digestion of forage crops. J. Brit. Grassl. Soc. 18:104-111. 